\title{
Zarostowe zapalenie oskrzelików w wyniku inhalacji toksycznych gazów i oparów — opis przypadku
}

\author{
Obliterative bronchiolitis due to inhalation of toxic gases and fumes - case report \\ Praca nie była finansowana
}

\begin{abstract}
Obliterative bronchiolitis is a rare pulmonary disease, characterised by narrowing and eventual obliteration of bronchioles by peribronchial and submucosal fibrosis. One of the identified causes of bronchiolitis is acute injury due to inhalation of toxic gases and fumes. Physiological criteria, essential in preliminary diagnostics, include irreversible airflow limitation, forced expiratory volume in 1 second (FEV1) $<60 \%$, and exclusion of other causes of airflow obstruction. Surgical lung biopsy with histologic examination confirms diagnosis definitely. Prognosis of obliterative bronchiolitis, irrespective of aetiology, is rather poor, and treatment is rarely efficacious. We present a young chemist exposed to inhalation of toxic gases and fumes due to lack of usage of any personal protective equipment. He was referred to our lung disease department because of shortness of breath on exertion and irreversible airflow limitation. Definitive diagnosis of obliterative bronchiolitis was established by histological examination of specimen from open lung biopsy.
\end{abstract}

Key words: obliterative bronchiolitis, constrictive bronchiolitis, bronchiolitis obliterans, toxic inhalation, small-airways obstruction

Pneumonol. Alergol. Pol. 2014; 82: 576-581

\section{Streszczenie}

Zarostowe zapalenie oskrzelików jest rzadką chorobą płuc, której istotą jest podśluzówkowe i okołooskrzelikowe włóknienie oskrzelików prowadzące do koncentrycznego zwężenia ich światła. Jedną z częstych przyczyn powyższych zmian jest inhalacja toksycznych gazów, oparów i dymów. Za kluczowe we wstępnej diagnostyce uważa się stwierdzenie nieodwracalnej obturacji ze zmniejszeniem wartości $\mathrm{FEV}_{1}$ poniżej $60 \%$, po wykluczeniu innych przyczyn tych zaburzeń. Ostateczne rozpoznanie opiera się na badaniu histologicznym wycinka płuca. Niezależnie od czynnika sprawczego, rokowanie jest złe, a efekty podejmowanych prób leczenia pozostają niezadowalające. W pracy przedstawiono przypadek młodego chemika narażonego wskutek niestosowania środków ochronnych na toksyczne działanie gazów i oparów. Duszność wysiłkowa oraz nieodwracalne zaburzenia obturacyjne stały się powodem diagnostyki chorego na oddziale chorób płuc. Na podstawie badania histologicznego wycinka płuca rozpoznano zarostowe zapalenie oskrzelików.

Słowa kluczowe: zarostowe zapalenie oskrzelików, zapalenie oskrzelików, obturacja drobnych dróg oddechowych, inhalacja toksycznych gazów

Pneumonol. Alergol. Pol. 2014; 82: 576-581

Adres do korespondencji: dr n. med. Jolanta Winek, III Klinika Chorób Płuc IGiChP, ul. Płocka 26, 01-138 Warszawa, tel.: 22 431 22 18, faks: 22 431 2408 ,

e-mail: j.winek@igichp.edu.pl

DOI: 10.5603/PiAP.2014.0076

Praca wpłynęła do Redakcji: 15.05.2014 r.

Copyright (C) 2014 PTChP

ISSN 0867-7077 


\section{Wstęp}

Zarostowe zapalenie oskrzelików jest rzadkim schorzeniem płuc dotyczącym oskrzelików końcowych i oddechowych. Jego istotą jest podśluzówkowe i okołooskrzelikowe włóknienie prowadzące do koncentrycznego zwężenia światła oskrzelików, aż do ich zamknięcia [1]. Włóknieniu towarzyszą zastój wydzieliny w świetle oskrzelików oraz przewlekły proces zapalny [2]. Do najlepiej poznanych i udokumentowanych przyczyn zarostowego zapalenia oskrzelików należą: inhalacja toksycznych gazów, oparów i dymów, ekspozycja na odpady organiczne oraz wirusowe i bakteryjne infekcje (Mycoplasma pneumoniae, Legionella pneumophila).

Analiza literatury na temat zarostowego zapalenia oskrzelików, włącznie z aktualną, przynosi wiele niejednoznaczności. Historycznie termin bronchiolitis obliterans obejmował zarówno zmiany z dominującym naciekiem zapalnym, jak i zmiany włókniejące. Aktualnie w wyniku obserwacji i ustaleń ekspertów oddzielono zarostowe zapalenie oskrzelików od grupy komórkowych zapaleń oskrzelików, a przede wszystkim od uznanego za chorobę śródmiąższową organizującego zapalenia płuc. Należy przy tym dodać, że zarostowe zapalenie oskrzelików w przeciwieństwie do dwóch pozostałych jest chorobą wyjątkowo rzadką i niestety, zwykle źle rokującą [3-5].

Wydaje się, że zachorowanie na zarostowe zapalenie oskrzelików zależy zarówno od siły działania czynnika sprawczego, jak i od indywidualnej odpowiedzi tkankowej pacjenta [6]. Charakter i obszar uszkodzeń dróg oddechowych wskutek inhalacji toksycznych substancji są uzależnione od wielkości cząsteczki i rozpuszczalności w wodzie. Uważa się, że cząsteczki większe niż $5 \mu \mathrm{m}$ zwykle nie docierają do pęcherzyków płucnych. Do obwodowych dróg oddechowych docierają gazy słabo rozpuszczalne w wodzie, jak $\mathrm{NO}_{2}$ i fosgen. Do uszkodzenia komórek wskutek ostrej ekspozycji na toksyny dochodzi zwykle w nieimmunologicznym mechanizmie tworzenia kwasów (tlenek azotu, fosgen, chlor, dwutlenek siarki), zasad (amoniak) i reaktywnych form tlenu i azotu. Powstające kwasy uszkadzają tkanki w mechanizmie koagulacji, zasady w mechanizmie upłynnienia śluzu z tworzeniem głębokich uszkodzeń oskrzelików, zaś reaktywne pochodne tlenu i azotu - w przebiegu peroksydacji lipidowej i utleniania białek. Niezależnie od mechanizmu, dochodzi do wzrostu ekspresji cytokin prozapalnych, co skutkuje nieodwracalnym ostrym uszkodzeniem tkanek wraz z uruchomieniem procesów naprawczych, odpowiedzialnym za włóknienie oskrzelików, które jest istotą choroby [7].

Wśród częstych przyczyn zarostowego zapalenia oskrzelików, obok infekcji i inhalacji toksycznych gazów, wymienia się choroby tkanki łącznej, zwłaszcza reumatoidalne zapalenie stawów, stosowanie leków, takich jak sole złota i penicylamina, a ponadto opisywane ostatnio przeszczepienia płuc, serca i szpiku. Rozpoznawany wówczas zespół obliteracyjnego zapalenia oskrzelików (BOS, bronchiolitis obliterans syndrome) ma charakter reakcji przewlekłego odrzucania przeszczepu. Zapadalność, diagnostyka i leczenie chorych z BOS są odmienne i nie będą omawiane w niniejszej pracy.

Z uwagi na mało charakterystyczny obraz kliniczny i radiologiczny kluczowe znaczenie zarówno w rozpoznawaniu, jak i monitorowaniu chorych na zarostowe zapalenie oskrzelików ma badanie spirometryczne. Turton i wsp. za kryterium identyfikacji chorych na zarostowe zapalenie oskrzelików przyjęli stwierdzenie nieodwracalnej obturacji ze zmniejszeniem natężonej objętości wydechowej pierwszosekundowej $\left(\mathrm{FEV}_{1}\right.$, forced expiratory volume in 1 second $)$ poniżej $60 \%$ wartości należnej, po wykluczeniu innych przyczyn obturacji. W badaniach czynnościowych, obok obniżenia odsetka natężonej pojemności życiowej wydmuchiwanej w czasie 1 sekundy natężonego wydechu $\left(\mathrm{FEV}_{1} \% \mathrm{FVC}\right.$, forced expiratory volume in one second \% of forced vital capacity), stwierdzano zmniejszenie maksymalnego uśrednionego przepływu wydechowego, gdy 75\% i $25 \%$ FVC pozostało do wydmuchnięcia (MEF 75\%-25\%, maximal expiratory flow $75 \%-25 \%$ ) oraz wzrost objętości zalegającej (RV, residual volume) [8].

Zarówno dane $\mathrm{z}$ wywiadu, jak i wyniki badań czynnościowych płuc mogą być niezwykle pomocne w diagnostyce, jednak ostateczne rozpoznanie zarostowego zapalenia oskrzelików opiera się na badaniu histologicznym wycinka płuca. Badanie histologiczne materiału pochodzącego z biopsji przezoskrzelowej płuca jest zwykle niemiarodajne, zaleca się więc biopsję chirurgiczną.

Niezależnie od czynnika sprawczego, rokowanie jest złe. U większości pacjentów proces chorobowy stopniowo postępuje, prowadząc do śmierci wśród objawów niewydolności oddechowej [9].

W pracy opisano przypadek młodego chemika, u którego diagnostyka ciężkich zaburzeń obturacyjnych doprowadziła do rozpoznania zarostowego zapalenia oskrzelików. 


\section{Opis przypadku}

Mężczyzna w wieku 26 lat, niepalący papierosów, został skierowany na oddział chorób płuc celem dalszej diagnostyki ciężkich zaburzeń obturacyjnych. Chory skarżył się na obserwowane od około 2 miesięcy uczucie dyskomfortu w klatce piersiowej oraz pogorszenie tolerancji wysiłku. W wykonanych ambulatoryjnie badaniach stwierdzono ciężkie nieodwracalne zaburzenia obturacyjne. Na podstawie obrazu radiologicznego (RTG) płuc wysunięto podejrzenie rozdęcia płuc.

W dzieciństwie z powodu częstych infekcji dróg oddechowych u pacjenta usunięto migdałki, z powodu zmian dysmorficznych twarzy wykonano plastyczną operację powiek. Od około 2 lat pracował jako chemik, w warunkach bezpośredniego narażenia na gazy: $\mathrm{NO}_{2}, \mathrm{SO}_{2}, \mathrm{NH}_{3}$, fosgen oraz opary chlorku metylenu i kwasów: siarkowego, solnego i azotowego. Podawał, że mimo dostępności maski ochronnej często pracował bez niej.

Po przyjęciu na oddział $\mathrm{w}$ badaniu przedmiotowym oraz badaniach laboratoryjnych nie stwierdzono istotnych odchyleń od normy. W RTG klatki piersiowej opisano w dolnych polach płucnych obustronne zmiany okołooskrzelowe. W tomografii komputerowej (TK) klatki piersiowej stwierdzono jedynie pogrubienie ścian oskrzeli, a w badaniu na wydechu nie uwidoczniono cech pułapki powietrznej. Wykonano bronchoskopię, w której poza bogatym rysunkiem drobnych i bardzo drobnych naczyń w obrębie drzewa oskrzelowego nie zauważono uchwytnych odchyleń. Wyniki badań wydzieliny oskrzelowej: posiewu bakteriologicznego ogólnego, mikologicznego oraz w kierunku BK (gruźlicy) były prawidłowe. W badaniu cytologicznym wydzieliny oraz histologicznym wycinka ze śluzówki oskrzela stwierdzono jedynie przewlekłe nieswoiste zmiany zapalne. Na podstawie wyniku badania immunofluorescencyjnego wydzieliny oskrzelowej wykluczono również świeżą infekcję wirusami grypy A i B, adenowiusem i syncytialnym wirusem nabłonka oddechowego (RSV, respiratory syncytial virus). Badania serologiczne w kierunku zakażenia Legionella pneumophila, Mycoplasma i Chlamydia pneumoniae nie przemawiały za aktywną infekcją.

W diagnostyce różnicowej zaburzeń obturacyjnych wzięto również pod uwagę zmiany w drobnych oskrzelach i oskrzelikach w przebiegu chorób tkanki łącznej. Chory negował zmiany skórne oraz bóle i obrzęki stawów. W surowicy krwi nie stwierdzono czynnika reumatoidalnego, miano przeciwciał przeciwjądrowych badanych metodą immunofluorescencji pośredniej wy- nosiło 1:100 (słabo pozytywne), typ świecenia jąderkowy i cytoplazmatyczny.

W celu oceny czynności płuc wykonano 6-minutowy test marszu oraz badanie pletyzmograficzne płuc. Stwierdzono cechy bardzo ciężkiej nieodwracalnej obturacji (FEV ${ }_{1} \% \mathrm{FVC}$ : 35,47; $\mathrm{FEV}_{1}$ : $1,34-31 \% \mathrm{~N}$ ) i rozdęcia (RV: $4,01-243,3 \%$; RV\%TLC: 48,95 - 203\%N). Pojemność dyfuzyjna dla tlenku węgla pozostawała w granicach normy. W 6-minutowym teście marszu chory pokonał należny dystans $687 \mathrm{~m}$ z obniżeniem saturacji z 98\% do $94 \%$. W spoczynku, jak również po wysiłku pacjent pozostawał wydolny oddechowo.

Wobec ciężkości zaburzeń czynnościowych, po wykluczeniu infekcyjnego tła powyższych zmian, chorego zakwalifikowano do otwartej biopsji płuca. W trakcie zabiegu pobrano brzeżny fragment płata środkowego i dolnego. W badaniu histologicznym pobranego materiału zwracały uwage zmienione drobne oskrzela i oskrzeliki, w obrębie których stwierdzano obszary aktywnego włóknienia błony śluzowej z obrzękiem podścieliska i skupieniami fibroblastów, przypominające ogniska fibroblastyczne. Włóknienie powodowało znaczne zwężenia światła oskrzelików. Miejscami miało charakter ubogokomórkowego włóknienia kolagenowego. W pobliżu oskrzelików pojawiały się niewielkie skupienia przewlekłych nacieków zapalnych z komórek limfoidalnych (ryc.1, 2).

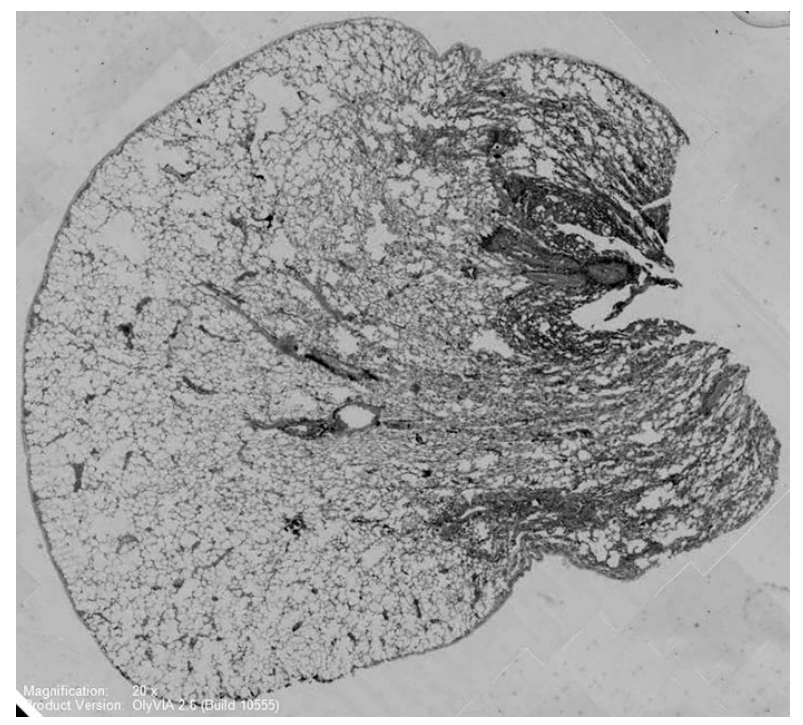

Rycina 1. Zarostowe zapalenie oskrzelików. Fragment miąższu płuca z widocznymi oskrzelikami o pogrubiałych ścianach, zwężonym świetle. Mikrofotografia. Małe powiększenie. Barwienie H + E

Figure 1. Constrictive bronchiolitis. The biopsy of lung tissue presents small fibrotic airways with narrowing lumen. Microphotograph. Low-magnification. Staining $\mathrm{H}+\mathrm{E}$ 


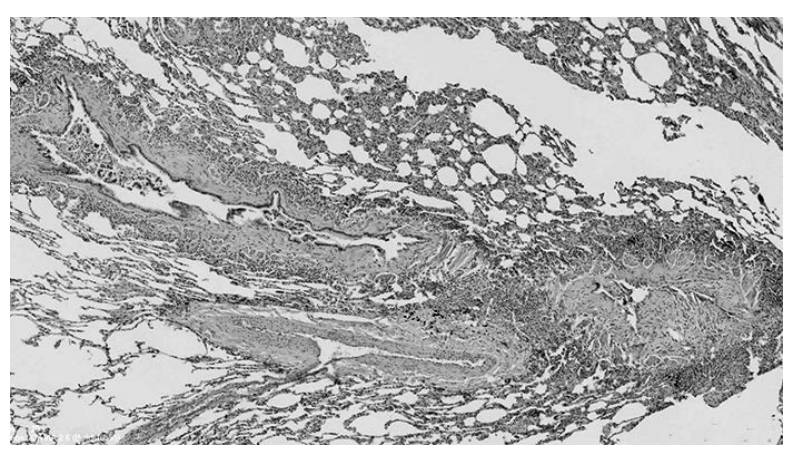

Rycina 2. Włóknienie i pogrubienie ściany oskrzelików ze zwężeniem światta. W jednym z oskrzelików (prawa strona) widoczne jest aktywne włóknienie fibroblastyczne. Mikrofotografia. Duże powiększenie. Barwienie $\mathrm{H}+\mathrm{E}$

Figure 2. Submucosal fibrosis of bronchioles with thickenning of walls. An active fibrosis with fibroblastic proliferation (right side) is seen. Microphotograph. High-magnification. Staining H + E

Na podstawie danych z wywiadu o narażeniu na szkodliwe substancje chemiczne, ciężkich nieodwracalnych zaburzeń obturacyjnych oraz obrazu histologicznego rozpoznano zarostowe zapalenie oskrzelików. Zważywszy, że najbardziej prawdopodobną przyczyną zarostowego zapalenia oskrzelików u tego pacjenta była stała ekspozycja na toksyczne gazy i ciecze, zalecono zaprzestanie pracy w laboratorium. Na podstawie pozytywnych doniesień z piśmiennictwa podjęto próbę leczenia makrolidami $[9,10]$. Wdrożono leczenie azytromycyną w dawce $250 \mathrm{mg}$ podawaną 3 razy w tygodniu. Chory dobrze tolerował leczenie. Po miesięcznej terapii zgłosił się na badania kontrolne. Nie dostrzegał istotnej poprawy tolerancji wysiłku. Zarówno w obrazie RTG klatki piersiowej, jak i w badaniach czynnościowych płuc (pletyzmografia i 6-minutowy test marszu) nie obserwowano istotnych zmian. Wobec powyższego zdecydowano o odstawieniu azytromycyny i wdrożeniu leczenia prednizonem w dawce $1 \mathrm{mg} / \mathrm{kg}$, co odpowiadało $70 \mathrm{mg} /$ dobę. Początkowo dobrze tolerowane leczenie po miesiącu zostało powikłane infekcją dróg oddechowych wymagającą antybiotykoterapii. Zdecydowano o redukcji dawki prednizonu do $60 \mathrm{mg} /$ dobę. Po 2,5 miesiąca leczenia chory nie zauważał poprawy, gorsza tolerancja wysiłku pozostawała niezmieniona. Wyniki zarówno 6-minutowego testu marszu, jak i spirometrii nie wykazywały istotnych zmian w odniesieniu do badań przed leczeniem. Obserwowano natomiast nawracające infekcje dróg oddechowych wymagające stosowania kolejnych antybiotyków. Zdecydowano o dalszej stopniowej redukcji dawki prednizonu, który wobec braku zarówno klinicznej, jak i czynnościowej poprawy po 6 miesiącach leczenia odstawiono. Stan pacjenta pozostawał stabilny, zgłaszał złą tolerancję wysiłku, która jednakże nie ulegała dalszemu pogorszeniu.

W badaniach kontrolnych wykonanych po roku obserwacji zarówno obraz TK klatki piersiowej, jak i wyniki badań czynnościowych: spirometrii i 6-minutowego testu marszu, nie zmieniły się istotnie. W ponad 3-letniej ambulatoryjnej obserwacji pacjenta nie stwierdzono istotnych zmian w obrazie klinicznym i radiologicznym. W kontrolnej spirometrii parametry oddechowe nie uległy istotnej zmianie: $\mathrm{FEV}_{1} / \mathrm{FVC}$ EX $38,74 \%$, zaś $\mathrm{FEV}_{1}-1,48(35 \% \mathrm{~N})$.

\section{Omówienie}

W pracy przedstawiono opis przypadku młodego chorego, u którego wskutek ekspozycji na toksyczne gazy i opary doszło do rozwoju nieodwracalnych ciężkich zaburzeń obturacyjnych. Przeprowadzona diagnostyka, włącznie z otwartą biopsją płuca, pozwoliła na ustalenie rozpoznania rzadko obserwowanego zarówno w poradniach, jak i na oddziałach chorób płuc - zarostowego zapalenia oskrzelików. Pomimo że wraz z rozwojem transplantologii wśród chorych po przeszczepieniu płuc, serca i szpiku rośnie zapadalność na BOS, chorzy ci zwykle pozostają pod stałą opieką ośrodków transplantologicznych.

Za jedną z dobrze poznanych i udokumentowanych przyczyn tej rzadko występującej choroby uważa się inhalację substancji toksycznych. Ekspozycja na toksyczne gazy i dymy może prowadzić do 3 różnych kliniczne zespołów chorobowych. Narażenie na wysokie stężenia może wywoływać obrzęk płuc lub zespół ostrej niewydolności oddechowej (ARDS, acute respiratory distress syndrome), które rozwijają się natychmiast lub z opóźnieniem 3-30 godzin po ekspozycji. Ekspozycja na niższe stężenia może prowadzić do kaszlu, duszności, krwioplucia z hipoksemią i sinicą, przy czym przebieg jest mniej gwałtowny i dramatyczny. U części tych chorych po 2-8 tygodniach od ekspozycji czy też po bezobjawowym okresie wstępnym pojawiają się narastająca duszność i nieproduktywny kaszel, zapowiadające rozwój zarostowego zapalenia oskrzelików [6].

Typowe dla przebiegu zarostowego zapalenia oskrzelików opisy przypadków pochodzą z okresu I wojny światowej. W prowadzonych wówczas działaniach wojennych wykorzystywano gaz musztardowy, podobnie jak w konflikcie Iran-Irak w 1980 roku. Szacuje się, że w trwającej 8 lat wojnie około 100000 Irańczyków zostało narażonych na działanie broni chemicznej, a blisko 50000 
eksponowanych na gaz musztardowy. Prowadzone przez ponad 20 lat badania laboratoryjne, radiologiczne, czynnościowe i histologiczne wskazują, że główną przyczyną przewlekłych dolegliwości ze strony dróg oddechowych było $\mathrm{w}$ tej grupie chorych zarostowe zapalenie oskrzelików [11, 12].

Podobne obserwacje pochodzą z badań Kinga i wsp. przeprowadzonych na grupie 80 amerykańskich żołnierzy odbywających służbę w Iraku i Afganistanie, skarżących się na postępującą duszność wysiłkową. U 49 z nich z uwagi na niejasny obraz kliniczny wykonano torakoskopową biopsje płuca. W 38 przypadkach rozpoznano zarostowe zapalenie oskrzelików, najprawdopodobniej wskutek ekspozycji na toksyczne gazy, a wśród nich dwutlenek siarki pochodzący z płonących kopalni siarki w Mosulu [13].

W opisywanym w niniejszej pracy przypadku chory zgłaszał bezpośrednie narażenie na gazy: $\mathrm{NO}_{2}, \mathrm{SO}_{2}, \mathrm{NH}_{3}$, fosgen oraz opary chlorku metylenu i kwasów: siarkowego, solnego i azotowego. Początkowo choroba przebiegała niezauważalnie, pojawiła się gorsza tolerancja wysiłku, a następnie uczucie dyskomfortu w klatce piersiowej. Do głównych dolegliwości w przebiegu zarostowego zapalenia oskrzelików należą — podobnie jak w opisywanym przypadku - narastająca duszność wysiłkowa oraz kaszel. W badaniu przedmiotowym u 40-60\% chorych stwierdza się piski, a w bardziej zaawansowanych stadiach choroby świsty i rzężenia. U części pacjentów, podobnie jak u omawianego pacjenta, w badaniu przedmiotowym nie obserwuje się żadnych odchyleń [9].

Badania radiologiczne klatki piersiowej oraz badanie przedmiotowe mają $\mathrm{w}$ diagnostyce zarostowego zapalenia oskrzelików ograniczoną wartość. U większości chorych w RTG klatki piersiowej nie stwierdza się zmian bądź też są to zmiany niespecyficzne, jak cechy różnego stopnia rozdęcia, osłabienie rysunku naczyniowego na obwodzie, siateczkowate i guzkowate zagęszczenia lub pogrubienie ścian oskrzeli. W omawianym przypadku uwidoczniono jedynie zmiany okołooskrzelowe w obrębie dolnych pól płucnych. Z uwagi na to, że proces chorobowy dotyczy oskrzelików, czyli pozbawionych chrząstki dróg oddechowych o średnicy poniżej $2 \mathrm{~mm}$, bezpośrednie uwidocznienie zmian w ich obrębie nie jest możliwe. Oceniane są pośrednie cechy zajęcia oskrzelików, takie jak obecność obszarów zwiększonej przejrzystości, mozaikowej perfuzji, poszerzenia bądź pogrubienia ścian oskrzeli, a także pułapki powietrznej w wydechowej fazie badania $[9,14]$. U prezentowanego pacjenta $\mathrm{w}$ tomografii komputerowej wysokiej rozdzielczości (TKWR) uwidoczniono jedynie pogrubienie ścian oskrzeli.

Kluczowe znaczenie w diagnostyce zarostowego zapalenia oskrzelików mają badania czynnościowe. Opisywany chory spełniał wymienione we wstępie kryteria Turtona i wsp. [8]. Stwierdzano nieodwracalną obturację z obniżeniem wartości $\mathrm{FEV}_{1}$ poniżej $60 \%$, która w omawianym przypadku wynosiła $31 \% \mathrm{~N}$, przy $\mathrm{FEV}_{1} \% \mathrm{FVC}$ 35,47 . W pletyzmografii zwracały uwagę cechy rozdęcia, będące konsekwencją ciężkiego zwężenia oskrzelików (RV: 4,01-243,3\%; RV\%TLC: $48,95-203 \%$ N). Pojemność dyfuzyjna dla tlenku węgla pozostawała w granicach normy. Jej spadek bywa obserwowany u chorych z ostrym przebiegiem choroby [9, 14].

Ostateczne rozpoznanie zarostowego zapalenia oskrzelików opiera się na badaniu histologicznym wycinka pobranego podczas chirurgicznej biopsji płuca. Za diagnostyczne uważa się, opisane w prezentowanym przypadku, koncentryczne zwężenie światła oskrzelików w wyniku podśluzówkowego i okołooskrzelikowego włóknienia $[1-3,10]$.

Niezależnie od etiologii zmian, rokowanie chorych na zarostowe zapalenie oskrzelików jest złe. Tym niemniej, u części z nich, podobnie jak u opisywanego pacjenta, po początkowej fazie stopniowej progresji choroby dochodzi do stabilizacji zmian. W 3-letniej obserwacji omawiany chory nie zauważał pogorszenia tolerancji wysiłku, a wyniki wykonywanych u niego badań czynnościowych i obrazowych nie ulegały istotnej zmianie.

Podstawowe znaczenie w postępowaniu z chorymi na zarostowe zapalenie oskrzelików wywołane ekspozycją na wziewne czynniki toksyczne ma eliminacja czynnika sprawczego. Wśród pacjentów eksponowanych na włókna nylonu zaprzestanie ekspozycji przynosi istotną poprawę, zaś u wdychających diacetyl przy braku istotnej poprawy zapobiega dalszemu pogorszeniu funkcji płuc [1].

Ponieważ u większości chorych pomimo przerwania ekspozycji dochodzi do stopniowej progresji zmian, a chorzy odczuwają duszność wysiłkową, podejmowane są próby leczenia. Ze względu na charakter zmian w oskrzelikach wziewne leki rozszerzające oskrzela są zwykle nieskuteczne. Podstawową rolę w leczeniu chorych na zarostowe zapalenie oskrzelików odgrywają, mimo ograniczonej skuteczności, doustne glikokortykosteroidy. Ich podanie jest zalecane szczególnie u chorych we wczesnej fazie choroby wywołanej ekspozycją na toksyczne 
dymy. Wskazana jest co najmniej 48-godzinna obserwacja w szpitalu, a następnie regularne badania kontrolne. Wczesne ustalenie rozpoznania i natychmiastowe wdrożenie leczenia mogą istotnie opóźnić postęp choroby [15, 16]. Leczenie powinno być kontynuowane przez co najmniej 2 miesiące, a następnie, aby zmniejszyć ryzyko nawrotu, stopniowo odstawiane. U części chorych konieczna jest kontynuacja leczenia małymi dawkami glikokortykosteroidów przez miesiące/lata. Problem stanowią pacjenci, u których początek choroby przebiega bezobjawowo, podobnie jak w opisywanym przypadku. Glikokortykoterapia rozpoczęta później może stabilizować proces chorobowy bądź też nie dawać efektu [1, 6, 17]. Decyzja o jej kontynuowaniu jest uzależniona od nasilenia działań niepożądanych i klinicznego efektu leczenia. U opisywanego chorego 6-miesięczne leczenie przy nawracających infekcjach dróg oddechowych wymagających antybiotykoterapii nie przyniosło zauważalnej poprawy.

Chorzy, u których w obrębie oskrzelików stwierdza się istotny komponent zapalny, nacieki z granulocytów obojętnochłonnych, mogą odnieść korzyść ze stosowania makrolidów. Ghanei na podstawie 6-miesięcznej obserwacji osób po ekspozycji na gaz musztardowy wskazuje, że przy braku istotnej poprawy w zakresie badań czynnościowych leczenie klarytromycyną i acetylocysteiną powodowało zmniejszenie nasilenia kaszlu i wykrztuszania [9-11]. W opisywanym przypadku w obrazie histologicznym dominowało włóknienie, a próba leczenia azytromycyną nie przyniosła poprawy.

Pomimo eliminacji czynnika sprawczego i podejmowanych prób leczenia, u większości chorych na zarostowe zapalenie oskrzelików proces postępuje, prowadząc do niewydolności oddechowej. W każdym takim przypadku wskazane jest rozważenie przeszczepienia płuc [6, 17].

\section{Wnioski}

Przedstawiony w niniejszej pracy przypadek zarostowego zapalenia oskrzelików stanowi przykład rzadkiej choroby płuc. Czynnikiem sprawczym w omawianym przypadku była najprawdopodobniej ekspozycja na toksyczne gazy i opary. Należy podkreślić, że dobry stan ogólny chorego, prawidłowy wynik badania przedmiotowego i niecharakterystyczny obraz radiologiczny nie mogą zwalniać z wnikliwej diagnostyki.
Kluczowe znaczenie w ustaleniu wstępnego rozpoznania mają szczegółowo zebrany wywiad oraz prawidłowo wykonane badanie spirometryczne. Potwierdzenie rozpoznania opiera się na badaniu histologicznym wycinka płuca. Wczesne ustalenie rozpoznania, zaprzestanie kontaktu z czynnikiem sprawczym i ewentualne wdrożenie leczenia istotnie poprawiają dalsze rokowanie chorych, które jednak w większości przypadków jest niestety złe.

\section{Konflikt interesów}

Autorzy nie zgłaszają konfliktu interesów.

\section{Piśmiennictwo:}

1. Garibaldi B.T., Illei P., Danoff S.K. Bronchiolitis. Immunol. Allergy Clin. N. Am. 2012; 32: 601-619.

2. Couture C., Colby T. Histopathology of bronchiolar disorders. Semin. Respir. Crit. Care Med. 2003; 24: 489-498.

3. Colby T.V. Bronchiolitis. Am. J. Clin. Pathol.1998; 109: 101109.

4. Epler G.R., Colby T.V., Mc Loud T.C. i wsp. Bronchiolitis obliterans organizing pneumonia. N. Engl. J. Med. 1985; 312: 152-158.

5. American Thoracic Society, European Respiratory Society. American Thoracic Society/European Respiratory Society international multidisciplinary consensus classification of the idiopathic interstitial pneumonias. Am. J. Respir. Crit. Care Med. 2002; 165: 277-304.

6. Lazarus S.C. Disorders of the intrathoracic airways. W: Mason R.J., Broaddus V.C., Martin T.R. i wsp. (red.). Murray \& Nadel's textbook of respiratory medicine. Saunders Elsevier, Philadelphia 2010; 1066-1079.

7. Dickson R.P., Schwartz D.A. Acute and chronic response to toxic inhalations. W: Fishman A.P., Elias J.A., Fishman J.A., Grippi M.A., Senior R.M., Pack A.I. (red.). Fishman's pulmonary diseases and disorders. Mc Graw-Hill Companies, New York 2007; 993-1008.

8. Turton C.W., Williams G., Green M. Cryptogenic obliterative bronchiolitis in adults. Thorax 1981; 36: 805-810.

9. Lynch J.P., Weigt S.S., DerHovanessian A., Fishbein M.C., Gutierrez A., Belperio J.A. Obliterative (constrictive) bronchiolitis. Semin. Respir. Crit. Care Med. 2012; 33: 509-532.

10. Cottin V., Cordier J.F. Bronchiolitis. W: Baughman R.P., duBois R.M. (red.). Diffuse lung disease. Springer, New York 2012; 343-363.

11. Ghanei M., Harandi A.A. Long term consequences from exposure to sulfur mustard: a review. Inhal. Toxicol. 2007; 19: 451-456.

12. Ghanei M., Harandi A.A., Tazelaar H.B. Isolated bronchiolitis obliterans: high incidence and diagnosis following terrorist attacks. Inhal. Toxicol. 2012; 24: 340-341.

13. King M., Eisenberg R., Newman J.H. i wsp. Constrictive bronchiolitis in soldiers returning from Iraq and Afghanistan. N. Engl. J. Med. 2011; 365: 222-230.

14. Devaconda A., Raoof S., Sung A., Travis W.D., Naidich D. Bronchiolar disorders. A clinical-radiological diagnostic algorithm. Chest 2010; 137: 938-951.

15. Tse R.L., Bockman A.A. Nitrogen dioxide toxicity. Report of four cases in firemen. JAMA 1970; 212: 1342-1344.

16. Jones G.R., Proudfoot A.T., Hall J.I. Pulmonary effects of acute exposure to nitrous fumes. Thorax 1973; 28: 61-65.

17. King T.E. Miscellaneous causes of bronchiolitis: inhalation, infectious, drug-induced and idiopathic. Semin. Respir. Crit. Care Med. 2003; 24: 567-576. 